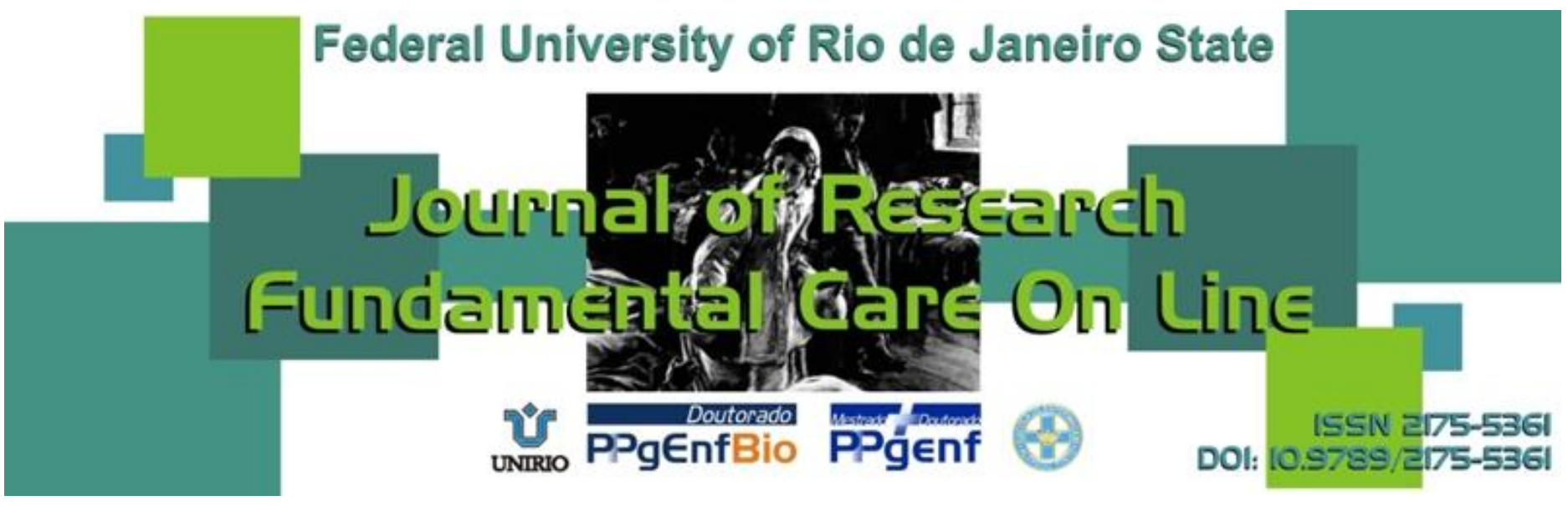

\title{
RESEARCH
}

\section{THE OCCURRENCE OF PRE-ECLAMPSIA IN WOMEN PREGNANT FOR THE FIRST TIME ATTENDING PRENATAL CARE CONSULTATION AT A UNIVERSITY HOSPITAL}

A OCORRÊNCIA DE PRÉ-ECLÂMPSIA EM MULHERES PRIMIGESTAS ACOMPANHADAS NO PRÉ-NATAL DE UM HOSPITAL UNIVERSITÁRIO.

LA INCIDENCIA DE PRE-ECLAMPSIA EN MUJERES PRIMIGESTAS EN CONTROL PRE-NATAL DE UN HOSPITAL UNIVERSITARIO

Thelma Spindola ${ }^{1}$, George Linconl dos Santos Lima ${ }^{2}$, Renata Lazone Cavalcanti ${ }^{3}$

\section{ABSTRACT}

Objective: To investigate the characteristics of pregnant for the first time attended at prenatal; identify the incidence of preeclampsia in pregnant for the first time attended consultations in prenatal care. Method: A descriptive, quantitative, retrospective, held at a University Hospital in Rio de Janeiro. The charts of women pregnant for the first time attended from 2008 to 2009 were analyzed with descriptive statistics support. Results: There were $264(56.3 \%)$ admissions of pregnants for the first time. Were part of the sample set 105 records. In this group, $43(40.9 \%)$ women showed in the edema, $2(1.9 \%)$ had proteinuria, $29(27.6 \%)$ had no abnormalities of blood pressure measurements. Conclusion: In the analyzed sample there was no record of preeclampsia, however 41 (38.9\%) women showed changes compatible with BP Disease Specific Hypertension in Pregnancy (HDP). Nurses have an important role in the multidisciplinary team, for early detection of complications during pregnancy contributes to reducing the incidence of maternal mortality and morbidity. Descriptors: Pre-eclampsia, obstetric nursing, high risk pregnancy, pregnant.

\section{RESUMO}

Objetivo: Conhecer o perfil das gestantes primigestas atendidas no pré-natal; identificar a incidência de pré-eclâmpsia em gestantes primigestas atendidas em consultas do pré-natal. Método: Estudo descritivo, quantitativo, retrospectivo, realizado num Hospital Universitário no Rio de Janeiro. Os prontuários de primigestas atendidas de 2008 a 2009 foram analisados com apoio da estatística descritiva. Resultados: Ocorreram $264(56,3 \%)$ admissões de primigestas. Fizeram parte do conjunto amostral 105 prontuários. Neste grupo, 43(40,9\%) gestantes não apresentaram edema; 2 (1,9\%) tiveram proteinúria; 29 (27,6 \%) não tiveram anormalidades nas aferições dos níveis tensionais. Conclusão: Na amostra analisada não houve registro de pré-eclâmpsia, todavia $41(38,9 \%)$ mulheres apresentaram alterações tensionais compatíveis com Doença Hipertensiva Específica da Gestação (DHEG). O enfermeiro tem um importante papel na equipe multiprofissional, para detecção precoce de intercorrências na gestação contribuindo para a redução da incidência da morbidade e da mortalidade materna. Descritores: Pré-eclampsia, Enfermagem obstétrica, Gravidez de alto risco, Gestantes.

\section{RESUMEN}

Objetivo: Investigar las características de primigesta embarazada asistieron prenatales, identificar la incidencia de preeclampsia en mujeres embarazadas primigestas asistió a consultas de atención prenatal. Método: Estudio descriptivo, cuantitativo, retrospectivo, realizado en un hospital universitario de Rio de Janeiro. Los gráficos de primigestas asistió desde 2008 hasta 2009 fueron analizadas con el apoyo estadística descriptiva. Resultados: Hubo $264(56,3 \%)$ ingresos primigestas. Se parte de la muestra establecida 105 registros. En este grupo, $43(40,9 \%)$ las mujeres no mostró edema, $2(1,9 \%)$ presentaron proteinuria, $29(27,6 \%)$ no presentaron alteraciones de las mediciones de la presión arterial. Conclusión: En la muestra analizada no había constancia de la preeclampsia, sin embargo, $41(38,9 \%)$ mujeres mostró cambios compatibles con la enfermedad de la hipertensión en el embarazo BP específico (HDP). Las enfermeras tienen un papel importante en el equipo multidisciplinario, para la detección precoz de las complicaciones durante el embarazo contribuye a reducir la incidencia de la mortalidad y la morbilidad maternas. Descriptores: Pre-eclampsia, Enfermería obstétrica, Embarazo de alto riesgo, Las mujeres embarazadas.

${ }^{1} \mathrm{PhD}$ in Nursing. Associate Professor, Department of Fundamentals of Nursing, Faculty of Nursing UERJ. Address: Edifício Paulo de Carvalho, Boulevard 28 de Setembro, 157 / $7^{\circ}$ andar. Vila Isabel. CEP.: 20551-030 - Rio de Janeiro - RJ. ${ }^{2}$ Degree in nursing from the School of Nursing Alfredo Pinto / UNIRIO, Nurse UPA Patience and Emergency Hospital Municipal Miguel Couto. ${ }^{3}$ Degree in Nursing from the College of Nursing Alfredo Pinto / UNIRIO.

J. res.: fundam. care. online 2013. jul./set. 5(3):235-44 


\section{INTRODUCTION}

The object of this study is the incidence of preeclampsia in primigravidae attended prenatal at a University Hospital in the city of Rio de Janeiro.

Pregnancy causes changes in the physical, psychological and social status of women and their families. ${ }^{1,2}$ It is a physiological phenomenon and its evolution is generally uneventful, though there is a portion of women who have specific characteristics and present some injury which leads to higher probabilities of unfavorable development during pregnancy, resulting in increased risk to the fetus and to his own mother.

3 Preeclampsia is one of the common problems that can occur during pregnancy, and the high incidence in primigravidae. ${ }^{4-5}$

A woman who conceives the first time, also called primigesta ${ }^{6}$, experiences a conflict situation, is happy to generate a living and at the same time feel anxiety by inexperience and concern related to pregnancy. In this sense, so there is a qualified prenatal care and humane, is recommended by the Ministry of Health ${ }^{1}$ that conducts cozy promote, and ensure easy access to quality health services, with actions that integrate all levels of care, from the basic to outpatient hospital care for high risk. Also emphasizes that the primary purpose of prenatal care is to welcome women from early pregnancy to ensure at the end of pregnancy, the birth of healthy children and ensuring maternal well-being. ${ }^{1}$

Interest in the topic was raised from the authors' work on projects "Orienting pregnant women in group prenatal Hospital Gaffrée and Guinle" and "Nursing Consultation in prenatal HUGG" in which covers various subjects related J. res.: fundam. care. online 2013. jul./set. 5(3):235-44 pregnancy, besides conducting physical examinations obstetric. It could be observed during the consultations that some primigravidae attended this service or had in its first consultation a framework for hypertension or had changes in blood pressure levels at some point during pregnancy.

Faced with this problem, it is important the closer monitoring of primigravidae since the genesis of pregnancy in order to contribute to the reduction of risk, considering that the better is the prenatal care in the quantitative and qualitative aspects, the lower rates obstetric complications. In this perspective, it is believed that it is the high incidence of pre-eclampsia in women who make primigravidae tracking prenatally.

Preeclampsia is characterized by increased pressure level (equal to or above 140 $\mathrm{mm} \mathrm{Hg}$ for systolic pressure and at or above 90 $\mathrm{mmHg}$ diastolic) accompanied by significant proteinuria (defined as at least $0.3 \mathrm{~g} / \mathrm{l}$ in urine 24 hours or $1 \mathrm{~g} / \mathrm{l}$ in simple sample) and generalized edema (face and hands) from the 20th week of pregnancy, and, in some cases, changes occur clotting and liver function. This triad associated with seizure sets a severe form called eclampsia. ${ }^{4}$

A pregnant woman with signs of preeclampsia may have compromised in several organs and systems like the vascular system, liver, kidney and brain. Regarding the fetus, can cause neuropathy, intrauterine growth retardation and fetal distress. ${ }^{7}$

In this context were defined as goals for research:

1 - Knowing the profile of pregnant primigravidae attended prenatal. 
Spindola T, Lima GLS, Cavalcanti RL.

2 - Identify the incidence of preeclampsia in pregnant primigravidae attended consultations in prenatal care.

The relevance of the study is related to the vulnerability of primigravidae and / or their unborn children to health hazards. Checking the incidence of preeclampsia in pregnant women may assist in providing health care for this woman, minimizing the maximum risk obstetrics. Thus, this study will contribute to the midwifery to provide subsidies for the discussion of assistance to pregnant primigravidae and widening the knowledge in the area related to the promotion and preservation of the health of this segment of the population.

\section{METHODOLOGY}

This is a descriptive study, quantitative, employing the technique of indirect observation and document analysis retrospective. The descriptive study aims to describe and elucidate the fundamental characteristics of a given population or phenomena, or else the establishment of relationship between variables. ${ }^{10}$ One of its peculiarities is the use of standardized techniques of data collection, such as the questionnaire, with the aim of studying the peculiarities of a group, their distribution by age, sex, origin, education level, health status, physical and mental.

In quantitative research, when using formal instruments to collect information, the data collected are quantitative, which means that information is numerical measurement results from formal and analyzed with statistical procedures. The scientists seek to go beyond the specific situation search, in which degree the search result can be generalized, as a criterion widely used to investigate the quality and relevance of a study of traditional search. ${ }^{11}$ The J. res.: fundam. care. online 2013. jul./set. 5(3):235-44
The occurrence of...

technique of document analysis, generally speaking, is an end in itself, with specific objectives that often involve hypothesis testing, requiring consultation with various types of files public or private.

The site chosen for the research was a midsize university hospital that offers the service of prenatal and maternity to SUS users. Located in the municipality of Rio de Janeiro, in the planning area 2.2, under the coordination of CAP 2.2, which covers the districts of Alto da Boa Vista, Flag Square, Grajaú and Andaraí, with a population of approximately 360,000 inhabitants.

The material used for the data collection were the medical records of pregnant women seen at antenatal service of that unit. We used the technique of documentary retrospective chart review of women primigravidae attended in 2008 and 2009. Were excluded from the sample set records of women who had gestational age less than 20 weeks, whereas the manual from the Ministry of Health and other studies that relate preeclampsia settles from the 20th week of gestation. ${ }^{1,7,8}$

The following variables were selected to compose the study: related to demographic, social, family history, medical history, and obstetric biological, main complaints, weight at the beginning and end of pregnancy, complications during pregnancy, gestational age at termination of pregnancy, weight gain, changes in blood pressure, and signs of edema, proteinuria and laboratory tests.

The data collection instrument $(\mathrm{DCl})$ was used a structured form with thirteen open-ended questions, eight and two closed mixed, totaling 23 questions. The data collection period was from February to March 2010. The medical records of pregnant women seen in the period from 2008 to 2009. The choice of time period and years were 
Spindola T, Lima GLS, Cavalcanti RL.

selected for the investigation random, so that had elements for the quantitative analysis with an expressive of information. Testing was performed by the application of ICD in five charts of primigravidae, which were not included in the computation general.

We respected the ethical aspects contained in Resolution 196/96 of the National Health Council / Ministry of Health The research project was appreciated by the Ethics and Research (CER) institutional and approved under number 60/2009. After the project was approved by the IRB, data collection proceeded to addressing the sector file of the institution to proceed to the medical records. Initially we had difficulty accessing these documents as a result of failures in the process of storage of this material by the institution.

Completed data collection, tabulation and proceeded to organize the findings by applying descriptive statistics using Excel as a resource software version 2007 . The discussion is supported by documents such as the Summary of Social Indicators IBGE ${ }^{13}$, Manuals Ministry of Health ${ }^{1,3,14}$ and other references that examine the theme.

\section{RESULTS AND DISCUSSION}

The results indicate that in the period 2008 to 2009 were admitted 264 (56.3\%) primigravidae a total of 469 calls. However, only did part of the sample set 105 records, whereas the rest (159) were not found in the file of the institution in the data collection phase of the research.

The results show that the age of the patients ranged between 12 and 39 years and is distributed as follows: 41 (39\%) between 20 and 25 years, 37 (35.2\%) between 15 and 19 years, 14 (13.3\%) between 26 and 30 years, 06 (5.7\%) under the age of 15 years, 04 (3.8\%) were older than 35 years of age and $03(2.8 \%)$ between 31 and 35 J. res.: fundam. care. online 2013. jul./set. 5(3):235-44
The occurrence of...

years. According to the Ministry of Health (2006), ages below 15 and above 35 years are considered high-risk factors during pregnancy. ${ }^{1}$

In the investigated group there are 43 (40.9\%) female adolescents. Whereas adolescence is a phase in which the human being is developing with biological changes, psychological and social well-structured yet, the superposition of pregnancy entails a physical and psychological burden, especially for adolescents 10 to 15 years old $(5.7 \%$ of young people studied), which increases vulnerability to maternal-fetal disorders and psychosocial. It is noteworthy that 07 (6.7\%) pregnant women were older than 30 years, this being a factor in the literature which can be associated with the occurrence of Gestational Hypertension Syndrome (SHG). ${ }^{8}$

Regarding education group is distributed as follows: 36 (34.3\%) completed high school, 24 (22.9\%) primary school, 14 (13.3\%) had incomplete secondary education and 11 (10,5\%) incomplete primary education, 10 (9.5\%) incomplete higher level and 06 (5.7\%) had higher education, 04 (3.8\%) patient records that were part of the sample set were without this information. The result shows $46.7 \%$ of pregnant women have not completed high school, indicating that low educational level is a factor that hinders the access of women to information and knowledge, which may adversely affect the conditions for selfcare, because it implies both assimilate received information about health care as at ease in seeking these cares. ${ }^{5}$ this sense, the Ministry of Health warns that poor education, less than five years of study fits into a risk factor for the current pregnancy.

With regard to professional activity, occupation or study, 48 (44.8\%) said they perform paid activities, such as selling, maid, administrative assistant, hairdresser, 
Spindola T, Lima GLS, Cavalcanti RL.

physiotherapist, technical nursing, among others. The result of the research refers to data in the Summary of Social Indicators 2009, which analyzed the proportion of women employed in the period from 1998 to 2008, revealing an increase in women's participation in the labor market, increasing from $42.0 \%$ to $47.2 \%$ for the whole country. ${ }^{13}$

On the other hand, people who had no paid work was distributed as follows: 20 (19.0\%) had activities related to home and 37 (35.2\%) said they were students. This group therefore does not make up the economically active population (EAP) as a result of their occupation. In this sense, the expenses related to motherhood and family formation may cause difficulties for mothers to have progress in schooling, which in turn affects their integration into the labor market and contribute to the continuation of the cycle of poverty with all bad consequences for the quality of life of women. ${ }^{1}$

It is worth adding that the socioeconomic and cultural factors influence the health of individuals and may determine different possibilities of access to health services, such as the individual's own initiative in seeking care, considering that once met the primary needs of survival, the individual tends to seek other levels of satisfaction. ${ }^{5}$

Regarding ethnicity, 37 (35.2\%) considered themselves to be non-white (NB) and 39 (37.1\%) called themselves white $(B)$. These results come against the IBGE information that compares the distribution by color or race population in the period 1998 to 2008, with a growth in the proportion of the population that is black or mixed states and a reduction of the population declares itself white. ${ }^{13}$ It is noteworthy that 29 (27.6\%) of the records were without a record of this information and the data of color or race that J. res.: fundam. care. online 2013. jul./set. 5(3):235-44
The occurrence of...

were part of the sample were collected from the medical history information, the information being superficial NB, not because measures with precision frequency of the black population, served in this unit, which is also a factor in the literature which can be associated with the occurrence of Gestational Hypertension Syndrome. ${ }^{8}$

Regarding marital status 74 (70.4\%) single, $24(22.8 \%)$ married, 02 (1.9\%) stable, 01 (0.9\%) was separated and 04 (3.8\%) records lacked this information. The findings indicate that the majority of women surveyed stated marital status, but did not report the presence of a companion. For the Ministry of Health this condition unfavorable sociodemographic (absence of a partner) may represent a risk factor for these pregnant women, whereas single women have a higher incidence of complications during pregnancy. In this sense, it is considered that for a good outcome of pregnancy is expected that the pregnant woman to the whole family to prepare for the changes, it is important the support and guidance of health professionals who will help the family cope with the problems arising with pregnancy.

As for family history, 59 (56.2\%) records of chronic hypertension, 05 (4.8\%) of pre-eclampsia, $15(14.3 \%)$ of chronic hypertension and preeclampsia, 23 (21.9\%) had no family history related to hypertension, $03(2.9 \%)$ records had no such information. The data show that $75.3 \%$ of pregnant women had reports of preeclampsia and / or chronic hypertension in the family. Previous studies show the personal or family history of preeclampsia and / or chronic hypertension as factors that increase the risk of developing the syndrome Hypertensive Gestational. ${ }^{5}$ According to the Ministry of Health ${ }^{1}$, a major cause of morbidity and maternal and fetal mortality are hypertensive 
complications in pregnancy, occurring in approximately $10 \%$ of all pregnancies and is more common in nulliparous women, women with hypertension for 04 years, history of hypertension prior to pregnancy and renal disease, or women with a family history of pre-eclampsia.

As gestational age at start prenatal care, $60(57.1 \%)$ women initiated in the second trimester, 40 (38.1\%) in the first quarter, 40 (3.8\%) in the third quarter, $01(1.0 \%)$ patient chart lacked this information. These findings show that $60.9 \%$ of the pregnant women started late prenatal monitoring, although the Ministry of Health recommend the initiation of prenatal care early, i.e. in the first trimester and are held at least six visits during prenatal care in order to have a host this woman from the beginning of pregnancy. In addition, some women may develop during pregnancy adversely, which may, from the 20th week of pregnancy cause a preeclampsia/eclampsia. ${ }^{1}$

In relation to weight change, only selected charts of primigravidae who began prenatal care in the first quarter and continued through the third quarter, totaling 38 (36.2\%) medical records so that we could evaluate the weight change. The other primigravidae, 67 (63.8\%) did not meet this criterion and therefore were not included in the analysis. We set the limits gains in kilograms $(\mathrm{kg})$ in late pregnancy, as recommended by the Ministry of health1 establishing a maximum gain of $7 \mathrm{~kg}$ for obese pregnant women and a maximum of $18 \mathrm{~kg}$ for pregnant women with low weight. We, therefore, 29 (76.3\%) women with weight gain between $7 \mathrm{~kg}$ to $18 \mathrm{~kg}, 7$ (18.4\%) pregnant women below this range and 2 (5.3\%) above that range.

Regarding the registration of edema during the prenatal period, the findings show that $43(40.9 \%)$ had no edema, 39 (37.1\%) were classified as edema $(+), 10$ $(9.5 \%)$ were rated as $(++)$ and $01(1.0 \%)$ showed severe edema with locker. In 12 (11.4\%) records did not record this information. According to the Technical Manual of Prenatal and Puerperium, verifying the presence of edema is aimed at early detection of the occurrence of edema and pathologic findings ranging from no edema $(-)$ to generalized edema (face, trunk and limbs) or which manifests itself by agreeing with or without hypertension or sudden increase in weight $(+++){ }^{1}$

In the analysis of medical records found that 9.5\% of primigravidae had records classified as $(++)$. According to the Manual of the Ministry of Health, this finding is classified when it has a lower limb edema limited to, the presence of hypertension or weight gain and / or proteinuria (+). When we compared the results of the study with the guidance of the Ministry of Health, we observed that women whose records classified as edema $(++)$ there was no information in the medical records regarding hypertension or weight gain and / or proteinuria.

Table 1 - Measurements of blood pressure recorded in the records of prenatal primigravidae in 2008-2009. Rio de Janeiro, 2010.

\begin{tabular}{lcc}
\hline $\begin{array}{c}\mathrm{N}^{\circ} \text {. of } \\
\text { measurements }\end{array}$ & $\mathrm{Fi}$ & $\mathrm{F} \%$ \\
\hline Inferior to 05 & 35 & 33,3 \\
5 to 6 & 43 & 40,9 \\
7 to 8 & 17 & 16,1 \\
9 to 10 & 09 & 8,5 \\
Over 10 & 01 & 0,9 \\
\hline Total & 105 & 100 \\
\hline
\end{tabular}

Table 2 - Changes in systolic blood pressure (SBP) and diastolic blood pressure (DBP) of primigravidae attended the prenatal period, from 2008-2009. Rio de Janeiro, 2010.

\begin{tabular}{|c|c|c|c|}
\hline Pression & $\begin{array}{c}\text { Variation } \\
(\mathrm{mmHg})\end{array}$ & $\mathrm{Fi}$ & $\mathrm{F} \%$ \\
\hline SBP & $\geq 30$ & 04 & 3,8 \\
\hline DBP & $\geq 15$ & 20 & 19,0 \\
\hline SBP & $\geq(30$ & 17 & 16,1 \\
\hline DBP & respectivelly & & \\
\hline SBP & Without changes & 29 & 27,6 \\
\hline DBP & - & 35 & 33,3 \\
\hline \multicolumn{4}{|l|}{ Incomplete } \\
\hline \multicolumn{4}{|l|}{ data } \\
\hline Total & & 105 & 100 \\
\hline
\end{tabular}

J. res.: fundam. care. online 2013. jul./set. 5(3):235-44 
Spindola T, Lima GLS, Cavalcanti RL.

Legend: SBP (systolic blood pressure), DBP (diastolic blood pressure).

For analysis of changes in blood pressure of pregnant women, tables 1 and 2 , was considered a minimum of 05 measurements recorded in the medical records, so records of 105 analyzed, only 70 had this information. We had 43 (40.9\%) women who had 5-6 measurements, 17 (16.1\%) underwent measurements 7-8, 9 (8.5\%) were 9-10 and 01 measurements $(0.9 \%)$ over 10 measurements.

The systolic blood pressure (SBP) $80 \mathrm{mmHg}$ was recorded minimum and maximum was 130 $\mathrm{mmHg}$ in all records, 04 (3.8\%) had chips analyzed variation of SBP $30-40 \mathrm{mmHg}$. Regarding the diastolic blood pressure (DBP), the minimum recorded in chips was $40 \mathrm{mmHg}$ and the maximum was $90 \mathrm{~mm} \mathrm{Hg}, 20$ (19.0\%) women had a variation of DBP $30-35 \mathrm{mmHg}, 17(16.1 \%)$ had a variation of less than $30 \mathrm{mmHg}$ in systolic and less than 15 $\mathrm{mmHg}$ in DBP.

They had abnormalities in their measurements $29 \quad(27.6 \%) \quad$ primigravidae investigated. The biggest record pressure levels found in the sample set was $130 \times 90 \mathrm{mmHg}$, however 35 (33\%) had incomplete data records which precluded analysis of this information.

According the authors ${ }^{5}$, if from 20 weeks pregnant to provide an increase of $30 \mathrm{mmHg}$ in systolic and / or $15 \mathrm{mmHg}$ in diastolic is considered that this woman has the hypertensive disorder of pregnancy (HDP). According to the Ministry of health1 caution is needed to avoid false positive diagnosis, recommending use this data as a warning sign and scheduling controls closer. From these findings we can say that in 70 primigravidae investigated, 41 (58.6\%) presented a framework of HDP.

Regarding the examination of abnormal elements and sediments (EAS) in urine, 63 (60.0\%) were unchanged, 15 (14.3\%) had urinary tract J. res.: fundam. care. online 2013. jul./set. 5(3):235-44
The occurrence of...

infection and only 02 (1.9\%) had proteinuria. In 25 (23.8\%) records did not record this information. The results showed $1.9 \%$ of pregnant women had proteinuria, which brings us the correlation between pre-eclampsia and proteinuria. Proteinuria is a late manifestation of preeclampsia and therefore an appropriate clinical approach to treat preeclampsia as pregnant women with hypertension again, even before proteinuria develop. ${ }^{4}$

With respect to complications during pregnancy, the findings show that the higher incidence of complications recorded in the consultations was the manifestation of episodes of urinary infection, a total of 15 occurrences. These data may be ratified by the Ministry of Health stating that urinary tract infection (UTI) is common in young women and is the most common clinical complication in pregnancy. Complements that $2 \%$ to $10 \%$ of pregnant women have asymptomatic bacteriuria may develop if left untreated, complications such as acute pyelonephritis, preterm labor (PTL), anemia and growth restriction intrauterine ${ }^{1}$.

The data obtained allow us to state that prenatal care is essential to quality maternal and child health, although as mentioned, pregnancy is a normal physiological event for most women. Thus, the findings confirm the importance of the early identification of the risk condition during pregnancy, since the incidence of eclampsia is higher among those who did not pre-natal or were linked to programs that do not prioritize the quality assistance. It is worth noting, also, the fact that eclampsia is a preventable disease, but how it affects women from socio-economically disadvantaged, their occurrence is related by access to early diagnosis and treatment. ${ }^{5}$

Another noticeable aspect was the number of records without complications record, reaching 
Spindola T, Lima GLS, Cavalcanti RL.

a total of $23(21.9 \%)$ of the 105 analyzed. These data indicate the importance of health professionals value the records to perform the care of pregnant women, and refer the recommendation of the Ministry of Health, noted that the notes should be made not only on the mother's card but also in the medical record unit. In addition, each query must reassess the risk obstetric and perinatal, and the presence of these records should be interpreted by health professionals as a warning sign. ${ }^{1}$

In this sense, it is worth noting that, lately, the nurse in the care of pregnant women in prenatal consultation has actively participated in the early evaluation of obstetric complications that could develop unfavorably and thus has contributed to the reduction of maternal and infant mortality. An effective prenatal care plays a key role in the process of labor and birth and rates of maternal and perinatal mortality. Achieving an effective prenatal care means having as a major goal of such assistance to identify factors that may put the maternal and fetal health at greater risk of adverse outcomes and know the right time to intervene, preventing or reducing the adverse consequences of these risks. ${ }^{15}$

Studies show the necessity of implementing a systematization of nursing care focused on this group of patients, which is considered a risk because of the particularities, symptomatology, clinical responses of patients, and especially the consequences of the disease preeclampsia (GHS) can bring to both mother and child. Considering the problem of the subject, it becomes necessary to discuss it in getting bases to promote a skilled nursing care and specific for this disease. ${ }^{17}$

\section{CONCLUSION}

The analysis of 105 medical records of primigravidae attended in the period of 2008-2009 J. res.: fundam. care. online 2013. jul./set. 5(3):235-44
The occurrence of...

in prenatal Hospital Gaffrée and Guinle - UNIRIO allowed us to define the profile of women who mostly 77 (73.3\%) had between 15 and 25 years, 36 (34.3\%) high school, 47 (44.8) paid activity, 39 (37.1\%) said they were white, 74 (70.5\%) are single, and 59 (56.2 \%) medical record had chronic hypertension in family history.

In the investigated sample set there was no record of preeclampsia, whereas the parameter set by the Ministry of Health to classify this disease (hypertension edema ++ proteinuria). However, 41 (58.6\%) women showed changes consistent with preeclampsia tension.

It can be observed in a significant quantity of records that lack of information made it difficult to perform the analysis of some variables. Thus, some data only contained early prenatal monitoring or were missing; others were only recorded at final follow-up. This observation can be pointed out as a limitation of the study.

In this sense, we believe in the importance of records in patients being extremely valuable tools for determining the quality of care provided to clients. It is noteworthy that the absence of information in the records may be due to forgetfulness of professional record information when they performed the service or by not valuing this practice.

The supply of skilled care is an essential component to reducing maternal and fetal mortality. A multidisciplinary and multi-trained and qualified; equipment availability, infrastructure laboratorial for the diagnosis and treatment of pre-eclampsia/eclampsia and highrisk pregnancies are indispensable for prenatal care quality.

In prenatal care, the nurse plays an important role in the multidisciplinary team, for early detection of complications, health education and referral to specialized care for severe cases 
Spindola T, Lima GLS, Cavalcanti RL.

helping to reduce the incidence of morbidity and maternal and infant mortality.

\section{REFERÊNCES}

1. Brasil. Ministério da Saúde. Pré-Natal e Puerpério. Atenção qualificada e humanizada. Brasília (DF): MS; 2006.

2. Buchabqui J, Capp E, Ferreira J. Adequação dos encaminhamentos de gestações de alto-risco na rede básica de atenção à saúde de Porto Alegre, Rio Grande do Sul, Brasil. Rev. Bras. Saúde Mater. Infant. 2006; 6(1): 23-9.

3. Brasil. Ministério da Saúde. Gestante de Alto Risco. Brasília (DF): MS; 2001.

4. Pascoal IF. Hipertensão e gravidez. Rev. Bras. Hipertens. 2002; 9(3): 256-61.

5. Gonçalves R, Fernandes RAQ, Sobral DH. Prevalência da Doença Hipertensiva Específica da Gestação em hospital público de São Paulo. Rev Bras Enferm. 2005; 58(1): 61-4.

6. Rezende Filho. Obstetrícia fundamental.

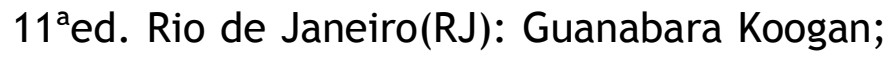
2008.

7. Dias BR, Piovesana AMSG, Montenegro MA, Guerreiro MM. Desenvolvimento neuropsicomotor de lactentes filhos de mães que apresentaram hipertensão arterial na gestação. Arq Neuropsiquiatr 2005; 63 (3-A): 632-6.

8. Assis TR, Viana FP, Rassi S. Estudo dos principais fatores de risco maternos nas síndromes hipertensivas da gestação. Arq Bras Cardiol 2008; 91(1):11-7.
The occurrence of...

9. Paraçoli JC, Parpinelli MA. Síndromes hipertensivas da gestação: identificação de casos graves. Rev Bras Ginecol Obstet. 2005; 27(10): 627-34.

10. Gil AC. Como elaborar projetos de pesquisa. 4ª ed. São Paulo (SP): Atlas; 2002.

11. Polit DF, Beck CT, Hungler BP. Fundamentos de pesquisa em enfermagem.

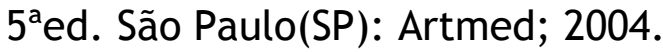

12. Brasil. MS. Fundação Oswaldo Cruz. Diretrizes e normas regulamentadoras de pesquisas envolvendo seres humanos. Resolução 196/96 do Conselho Nacional de Saúde. Brasília (DF): MS/ FIOCRUZ; 1996.

13. Brasil. IBGE. Departamento de População e indicadores sociais. Síntese de indicadores sociais. Rio de Janeiro (RJ): IBGE; 2009.

14. Brasil. Ministério da Saúde. Gestação de alto risco. Manual técnico. $5^{\mathrm{a}}$ ed. Brasília (DF): Ministério da Saúde; 2010.

15. Dotto LMG, Moulin NM, Mamede MV. Assistência pré-natal: dificuldades vivenciadas pelas enfermeiras. Rev Latino-am Enfermagem 2006; 14(5): 682-8.

16. Aguiar MIF, Freire PBG, Cruz IMP, Linard AG, Chaves ES, Rolim ILTP. Sistematização da assistência de enfermagem a paciente com síndrome hipertensiva específica da gestação. Rev.Rene. 2010; 11(4): 66-75.

17. Cunha KJB, Oliveira JO, Nery IS. Assistência de enfermagem na opinião das mulheres com pré-eclâmpsia. Esc Anna Nery R Enferm 2007; 11(2): 254-60. 
Spindola T, Lima GLS, Cavalcanti RL.

Received on: 06/07/2012

Reviews required: 02/03/2013

Approved on: 01/04/2013

Published on: 01/07/2013

J. res.: fundam. care. online 2013. jul./set. 5(3):235-44 